\title{
Measuring the Effect of the EITC on Marriage Penalties and Bonuses
}

Janet Holtzblatt

Office of Tax Analysis

Department of the Treasury

Washington, D.C. 20220
Robert Rebelein

Department of Economics

University of Cincinnati

Cincinnati, Ohio 45221

October, 1999

Revised: May 22, 2000 


\begin{abstract}
In 2000, the EITC will increase marriage penalties by at least $\$ 3.1$ billion (10.4 percent) and reduce marriage bonuses by $\$ 439$ million (1.5 percent). Over half of EITC-related marriage penalties will be attributable to couples who currently are ineligible for the EITC because their income is above $\$ 30,000$. However, estimates of marriage penalties and bonuses are very sensitive to assumptions regarding a couple's living arrangements and custody agreements if they do not file joint returns. Recent proposals to provide marriage penalty relief through the EITC are well-targeted to lower-income taxpayers but vary in their ability to reduce marriage penalties.
\end{abstract}




\section{Measuring the Effect of the EITC on Marriage Penalties and Bonuses}

According to the General Accounting Office (1996), there are 59 provisions in the income tax code that either penalize or reward marriage. ${ }^{1}$ The presence of marriage penalties and bonuses in the income tax code raises at least three concerns. First, one goal of tax policy is horizontal equity, or the equal tax treatment of equals. But the presence of marriage penalties and bonuses implies that two couples, who are similar except for the presence of a marriage license, can be taxed differently on the same amounts of income. Second, marriage penalties and bonuses may affect taxpayers' behavior by distorting decisions to either marry or work. Third, marriage penalties and bonuses may encourage taxpayers to evade tax liabilities by misreporting marital status and other family characteristics to the tax authorities.

These concerns are particularly important when considering the impact of the earned income tax credit (EITC). The EITC is a refundable tax credit that has been supported by many because they view it as fair, pro-family, pro-work, and relatively simple to administer. If the design of the EITC results in marriage penalties and bonuses and these penalties and bonuses adversely affect equity, taxpayer behavior, or compliance, then the credit may not be fully achieving the goals of its supporters.

Because the EITC initially increases and then declines with income, a marriage license can make a significant difference in the amount of the credit received by a couple. For example, two very low-wage workers with a child may receive a marriage bonus if they file a joint return, because their combined income will entitle them to a larger EITC than they can receive, in combination, as two unmarried filers. On the other hand, a two-earner couple with children and $\$ 35,000$ of combined income will be ineligible for the credit if married, but may be eligible for a sizable credit if they do not marry and, instead, live together and raise a family. Although their 
income and family responsibilities may be very similar, these married and unmarried couples are not treated the same under the income tax code.

Marriage penalties and bonuses in the EITC raise further questions because the credit is targeted to low-income families. These families are also subject to marriage penalties associated with needs-based transfer programs. As the number of single parent families has grown over the past three decades, concern has also grown that transfer programs may have spurred this growth by discouraging marriage. Marriage bonuses in the EITC may partially or fully offset the marriage penalties caused by the transfer system. But the credit may also give rise to marriage penalties, which can compound the effects of the transfer system. Thus, it is critical, as some recent research has, to take into account both the tax and transfer systems when studying family formation decisions (Dickert-Conlin, 1999; Eissa and Hoynes, 1999)

Another source of concern are the findings from an IRS study that over 20 percent of the credit was claimed in error in 1994 and that nearly one-third of EITC overclaims were due to married taxpayers misreporting their filing status on tax returns (Scholz, 1997; McCubbin, 1999). Some of the errors may simply reflect taxpayer confusion over the rules regarding filing status. But it is also possible that some taxpayers may respond to marriage bonuses and penalties by misreporting filing status in order to evade taxes. If true, understanding marriage penalties and bonuses in the tax system may provide further insight into ways to improve tax compliance. Since EITC noncompliance has been the subject of much scrutiny in recent years, particular attention is warranted to the marriage penalties and bonuses caused by the credit's design.

Each of these concerns is generated by the same fundamental issue: the relative tax treatment of single and married taxpayers. In spite of this common issue, it is unfortunately not possible to derive a unique measure of marriage penalties and bonuses that can simultaneously 
address concerns as complex and diverse as horizontal equity, decisions to marry or work, or taxpayer compliance.

For example, measuring the effect of marriage penalties and bonuses on horizontal equity requires comparing tax liabilities of couples who are similar in all regards, except for the presence of a marriage license. Thus, we assume that a couple, if not married, would still live together and make consumption, investment, and child-rearing decisions jointly. Using this method, the EITC is found to increase total marriage penalties in the income tax by $\$ 3.1$ billion (10.4 percent) and reduce marriage bonuses by $\$ 439$ million (1.5 percent) in 2000 . Nearly 63 percent of the EITC-related marriage penalties accrue to couples who are ineligible for the EITC as joint filers because their combined income, which may be as much as $\$ 60,000$, is too high.

This may also be a logical starting point for examining the impact of marriage penalties and bonuses on the decision to cohabitate rather than marry. But an analysis of other family formation choices, such as the decision to separate or divorce, may require different measures of marriage penalties and bonuses. The income tax code does not simply distinguish between married and single statuses by the presence of a marriage license, but also accounts for differences in living arrangements among couples, particularly among those who have children. If we instead assume that the couple, if not married, would live apart and that the lower-earner would have custody of the children, the EITC is found to increase total marriage penalties by $\$ 9.9$ billion ( 31.7 percent) and reduce marriage bonuses by $\$ 5.7$ billion (9.8 percent). This method increases the impact of the EITC on marriage penalties because even couples with incomes over $\$ 60,000$ could qualify for the credit if eligibility were based only on the lower earning spouse's income. Under this measure, nearly all (93 percent) of the EITC-related 
marriage penalties are incurred by couples whose incomes exceed the current EITC eligibility cut-off.

The preceding measures assume that taxpayers would not reorganize their living arrangements simply to avoid income taxes. These measures also assume taxpayers would comply with the tax code. Measuring the impact of marriage penalties and bonuses on tax avoidance or evasion requires a third method that allows taxpayers to either reorganize or misreport their living arrangements to the tax authorities in order to minimize their tax liabilities. Some taxpayers would find that their combined tax liabilities as unmarried filers will be minimized by allocating children to the higher earner, while others would find it more beneficial to assign custody of the children to the lower earner. This measure also gives taxpayers the option to divide custody of their children and thus both spouses, if eligible, can claim the EITC. Using such a measure, the EITC is found to increase marriage penalties by $\$ 12.8$ billion $(29.7$ percent) and reduce marriage bonuses by $\$ 1.5$ billion (5.7 percent). Under this measure, over 83 percent of the EITC-related marriage penalties are attributable to couples whose combined incomes are too high to qualify for the EITC as joint filers.

The paper is organized in the following manner. We first consider how trade-offs between various tax policy goals lead to marriage penalties and bonuses in the income tax and, in particular, the EITC. We next discuss the ways the tax code differentiates between married and unmarried filing statuses. After reviewing alternative ways to measure marriage penalties and bonuses, we estimate the extent to which the EITC contributes to marriage penalties and bonuses in the income tax. Further, we examine the distribution of EITC-related marriage penalties and bonuses by adjusted gross income classes and by current receipt of the EITC. We consider how these results are affected by alternative assumptions regarding a couple's living arrangements, 
custody agreements, and division of unearned income if they did not file joint returns. Finally, we look at the extent to which current legislative proposals to expand the EITC reduce marriage penalties and bonuses in the income tax.

\section{Sources and Implications of Marriage Penalties and Bonuses}

In the United States, the personal income tax is based on the income of the individual or, if married, the couple. ${ }^{2}$ Since 1948 , spouses have been effectively allowed to split income when filing a joint return. Married couples can file separate income tax returns, but most file joint returns because their income taxes are generally lower than if they opted for "married filing separate" status. For example, taxpayers are ineligible for the EITC or the child and dependent care tax credit if they claim "married filing separate" status.

A couple has a marriage penalty if they owe more income tax filing a joint return than the spouses would pay if they were unmarried and each were taxable as a single or head of household filer. Conversely, a couple has a marriage bonus if they owe less income tax filing a joint return than the spouses would pay if they were unmarried and each were taxable as a single or head of household filer.

Marriage penalties and bonuses are difficult to eliminate because they are often the byproducts of trade-offs among many policy goals. By treating the married couple as a distinct tax unit, the personal income tax recognizes that spouses share resources and make consumption and savings decisions together. From a practical perspective, it may be difficult to disentangle the income or expenses of one spouse from the other. The current tax code achieves horizontal equity among married couples because couples with equal combined incomes generally pay the

same amount of taxes, regardless of the allocation of income between spouses. ${ }^{3}$ However, as 
Bittker (1975) and many others have shown, a tax system cannot simultaneously have neutrality toward marriage, progressivity, and equal taxes of couples with the same total incomes. Graduated tax rate schedules and phase-outs of deductions and credits contribute to the progressivity of the tax code, but also can lead to marriage penalties when spouses' incomes are combined. Social policy considerations may also affect both the design of tax systems and the magnitude of marriage penalties and bonuses. During recent policy debates on the Federal role in the provision of child care assistance, marriage bonus-enhancing tax cuts have been proposed for families with stay-at-home parents.

The design of the EITC provides further evidence of the trade-offs that are made between the goal of marriage neutrality and other tax and social policy goals. For example, two of the most fundamental goals of the EITC are to encourage work, particularly among those with little or no attachment to the labor force, and to lift working families out of poverty. Three design features of the EITC contribute toward the achievement of these goals. First, individuals must have earned income to qualify for the EITC. Second, the EITC initially increases with earned income at a maximum rate of 40 percent, thus offsetting the disincentive effects that may be associated with a 15 percent social security tax rate and a 24 percent food stamp benefit reduction rate. Third, the maximum amount of the EITC was raised in 1993 with the goal of reducing the likelihood that a family of four with one full-time minimum wage worker lived in poverty. In 2000 , the maximum EITC will be $\$ 3,888$.

In addition to encouraging work, the first two features also create marriage bonuses, and the third feature - the size of the maximum credit - affects the magnitude of these bonuses. For example, by marrying an unemployed single parent with little or no taxable income, a low- 
income childless worker will always qualify for a much larger EITC than if he or she remained unmarried.

Another goal of tax policy is to raise sufficient revenues to pay for spending programs. Concerns about fiscal responsibility prevent policymakers from extending eligibility for this nearly $\$ 4,000$ tax credit to all taxpayers, but limiting benefits to those with the greatest needs causes marriage penalties. The magnitude of these penalties depends on the size of the credit and the extent to which eligibility for the credit is limited to those with the greatest needs.

Eligibility for the EITC is limited in two ways. First, after reaching a maximum value, the EITC decreases with modified adjusted gross income (earned income, if greater) until it is fully phased out at $\$ 31,152$ (for a taxpayer with two or more children). Second, taxpayers are also ineligible for the EITC if their investment income, including interest, dividends, net capital gains, net rents and net royalties, exceeds $\$ 2,400$.

Finally, policymakers have used the EITC to adjust for differences in ability to pay among taxpayers based on their family responsibilities. Until 1994, the EITC was available only to taxpayers if they resided with children for over half the year, although the amount of the credit did not vary with the number of children in the family. This had two consequences. On the one hand, the EITC could result in a significant bonus when a childless worker married a nonworker with children. On the other hand, it created a sizable penalty when two low-income workers, each with at least one child, married; instead of qualifying for two credits, the couple would only be eligible for one credit when married.

Recent legislative changes have reduced the magnitude of both these effects. Legislation in 1990 and 1993 entitled families with two or more children to a somewhat larger EITC than those with one child. At the maximum credit amounts, a family with two or more children 
receives a credit that is 165 percent of the amount received by families with only one child. This differential reduces - but does not eliminate - the marriage penalty caused by the cap on the number of EITC qualifying children.

In addition, since 1994, very low-income taxpayers who do not reside with children have been eligible for a small EITC that equals, at most, the employee contribution for social security taxes. This provision reduces EITC-related marriage bonuses that occur when a very low-wage childless worker marries a nonworker with children, but may increase penalties when two very low-wage childless workers marry.

Distinguishing between households

As noted above, the tax code treats married couples, with the same total income, equally, thus achieving a measure of horizontal equity. Horizontal equity comparisons can encompass other types of households as well. Brazer (1980) observed that a household might consist only of single individuals who share resources and otherwise appear to act as an economic unit in much the same manner as the marital unit. He argued that such households can be economically equivalent to marital units, and that treating married couples, but not similar types of households, as the unit of taxation can lead to another type of horizontal inequity in the tax code.

Brazer suggested that horizontal equity could be improved if the basic filing unit was the household, but he recognized that this would be difficult to administer because of the absence of an easily identifiable and readily verifiable group outside marriage. Alternatively, these inequities could be eliminated if the individual was the filing unit. But under a progressive income tax, married couples, with the same combined income, could pay vastly different amounts of taxes if the income tax was based on an individual filing unit. 
There is a third option that Brazer did not consider. Even within the context of a progressive income tax with joint filing for married couples, special rules have been created that recognize certain similarities between married couples and other types of households but that only apply in limited situations. As a result, there are some circumstances in which married individuals may be treated as if they were unmarried, and other circumstances in which unmarried individuals may have to take into account the income (or support) of others in their household when computing their tax liability.

First, while married individuals generally cannot file for the EITC on separate returns unless they are legally separated from their spouses, there is an exception for "abandoned spouses." The abandoned spouse rules apply to certain provisions in the tax code (such as head of household filing status) and pre-date the EITC. The rules were enacted to address concerns about low-income taxpayers who did not live with their spouses and who could not afford the legal expenses associated with divorce or legal separation, although they are also applicable to higher-income taxpayers. Under the rules, abandoned spouses are married individuals who have not lived with their spouses for the second half of the tax year, have not obtained a legal separation, and pay over half the costs of maintaining the homes in which they and their dependent children reside. If they meet these conditions, they may file as heads of households and, if eligible, claim the EITC. Thus, some married individuals can be treated, for EITC purposes, as if they were single. Their spouses, however, would be required to file as "married filing separate" unless they also meet the abandoned spouse conditions, and thus the effect of the abandoned spouse rule on the couple's combined tax liability is ambiguous.

Second, an adjusted gross income ("AGI") tiebreaker rule can affect EITC eligibility among individuals who share a home and the responsibility for the care of a child. For example, 
if two unmarried individuals live together and have a child, both could potentially be eligible to claim the child and receive the EITC. The AGI tiebreaker determines which of the two parents receives the credit. Under this rule, only the parent with the higher modified AGI can claim the EITC on behalf of the child. The lower earner may not claim the childless EITC.

Through the AGI tiebreaker, the EITC eligibility rules recognize that households consisting of two single individuals who live together and care for children may make economic decisions as a unit. ${ }^{4}$ Their circumstances are different from those in which the separated or divorced parents live apart. But because the AGI tiebreaker rule does not treat cohabiting single parents and married parents exactly alike, marriage penalties and bonuses may still occur, although their magnitude may be smaller than for couples who live apart.

Consider the effects of marriage on the tax liability of two workers, one with earnings of $\$ 18,000$ a year and the other who earns $\$ 12,000$ a year. The couple initially lives apart, and the lower-earner is the custodial parent of the couple's two children. When the couple marries and their income is combined, their combined AGI falls within the credit's phase-out range and the EITC is reduced by $\$ 3,645$ from $\$ 3,888$ to $\$ 243$. If, instead, the unmarried couple initially lived together with their children, the couple would be entitled to a smaller EITC -- only $\$ 2,770$ - than if they had lived apart; marriage would reduce their EITC by $\$ 2,527$ to $\$ 243$.

Undeniably, abandoned spouse rules and AGI tiebreakers add complexity to the tax code. As Brazer noted, it is difficult to recognize and verify informal household arrangements. A recent IRS compliance study (Scholz, 1997; McCubbin, 1999) shows that failure to comply with the AGI tiebreaker rule is a significant source of EITC errors, either because taxpayers do not understand the rules or purposely ignore them. The study also reveals that some married taxpayers claim head of head household status even when they do not meet the abandoned 
spouse criteria, although again the data do not reveal the extent to which such errors are caused by intent or confusion.

Ellwood (1999) speculates that rules, such as the AGI tiebreaker, are rarely applied in practice. When examining the effect of the EITC on cohabitation, he assumes that the woman, regardless of her income relative to the income of the man in the house, would claim the EITC. But while the findings of the IRS compliance study show that some taxpayers disregard the AGI tiebreaker, there is little, if any, data to test Ellwood's speculation that the rules are rarely applied. Taxpayers do not check boxes on their tax return to indicate that they "won" the AGI tiebreaker or that they are abandoned spouses, and the IRS compliance study does not contain extensive information on the characteristics or living arrangements of compliant taxpayers. Thus, neither the compliance study nor any other IRS data reveal the important converse: the number of individuals who are accurately complying with either the AGI tiebreaker or abandoned spouse rules.

\section{Measuring Marriage Penalties and Bonuses}

Aggregate measures of marriage penalties and bonuses can be derived by "divorcing" married couples or by "marrying" single individuals. Starting with married individuals requires making assumptions about how, if they were no longer married, they would allocate income, expenses, and children and other dependents. Assumptions must also be made regarding whether or not the couple would reside together, and if not, which parent(s) would have custody of the child(ren). Starting with single individuals requires either estimating the earnings of their potential (but unobservable) spouses (Dickert-Conlin and Houser, 1998), or focusing only on those single individuals for whom something may be known about their prospective spouses 
(Feenberg and Rosen, 1995; Alm and Whittington, 1997; Ellwood, 1999). Under either scenario, assumptions must also be made regarding how marital status affects behavior such as work effort or child care expenditures.

Most studies of marriage penalties and bonuses have taken the former approach and "divorced" married couples (Feenberg and Rosen, 1995; Alm and Whittington, 1996; Congressional Budget Office, 1997; Bull, Holtzblatt, Nunns, and Rebelein, 1999). However, these studies differed in how they reorganized the family unit and its financial and living arrangements under the assumption that the couple is no longer married.

For example, some studies have assumed taxpayers would reorganize the family unit in ways that would minimize their tax liability. The tax minimization method assumes that if taxpayers could file as single, they would allocate their income, exemptions, adjustments, deductions, and credits in a manner which minimizes their combined tax liability. Feenberg and Rosen assumed couples would minimize tax liability by allocating all but one child exemption to the higher income spouse; if there were two or more children, the lower-earner spouse was assumed to claim one child exemption. Spouses with child exemptions were then allowed head of household filing status and, if eligible, the EITC.

Other studies have adopted an empirical method. Under the empirical method, marriage penalties and bonuses are estimated using information about the effects of actual life-events such as marriage, divorce, or cohabitation - on the allocation of children, income, and expenses. Observing that most single-parent households are headed by a female, Alm and Whittington suggested that the wife be assumed to claim the child exemptions, head of household filing status, and the EITC. They found that during the 1980s, their empirical method generated net marriage bonuses, while a tax minimization method, similar to the one used by Feenberg and 
Rosen, resulted in net marriage penalties. By 1994, that disparity disappeared, and Alm and Whittington estimated an average net marriage penalty of $\$ 375$ under both methods.

Few studies look at the effect of the EITC, in isolation, on marriage penalties and bonuses. CBO (1997) measured marriage penalties and bonuses under 1996 law using a sample of married couples who had filed joint returns. CBO rejected both the empirical and tax minimization methods and instead allocated income and dependents based on specific rules thought to reflect those that might be included in possible Congressional marriage penalty relief bills. Nonetheless, some of their assumptions, particularly those dealing with the allocation of child exemptions and filing status, are the same as those used by Feenberg and Rosen. CBO found that the EITC increased total marriage penalties by about $\$ 11.8$ billion (or over 40 percent), but had a negligible effect on marriage bonuses.

Using the Panel Survey of Income Dynamics, Ellwood (1999) measures the change in the EITC among couples between the year prior to marriage and the first full year following marriage. While marriage does not affect EITC eligibility for most newlyweds, Ellwood finds that the EITC declines an average of $\$ 1,505$ for 16 percent of couples after marriage and increases by an average of $\$ 1,367$ for 11 percent of couples. Unlike most studies, Ellwood's estimates of marriage penalties and bonuses reflect non-tax factors that change after marriage. For example, among the couples who experience an increase in the EITC, over half also had their first child after marriage.

\section{Choosing among approaches}

We estimate marriage penalties and bonuses using the Treasury Department's Individual Tax Model (ITM). The ITM is a microsimulation model based on the Statistics of Income (SOI) sample of tax returns for Tax Year 1995. Because the SOI is a cross-sectional sample, the ITM 
does not contain any information regarding the marital history of taxpayers. The ITM also does not contain the demographic data that would be required to predict the earnings of an unmarried individual's potential spouse. Without such information, it is difficult to estimate marriage penalties and bonuses using the single filers in the ITM. We therefore follow the more conventional approach of "divorcing" married couples to estimate marriage penalties and bonuses. This approach allows us to measure marriage penalties and bonuses among those couples who have chosen to marry. It may not, however, be adequate for measuring potential marriage penalties and bonuses observed by single individuals as they consider the tax consequences of marriage. This is particularly true if unmarried individuals differ in fundamental ways (such as earnings and presence and number of children) from those who are married.

In an earlier paper (Bull, Holtzblatt, Nunns, and Rebelein, 1999), we considered and rejected the empirical method for allocating income, expenses, dependents, and living arrangements between the two spouses. Information on how cohabiting or divorced couples split assets and family responsibilities could be used to derive assumptions on how married couples might act if they were not married, but those who already cohabitate or divorce may be fundamentally different from those who remain married and subject to either marriage penalties or bonuses under the tax code. We also rejected a tax minimization strategy. A complete tax minimization model would be conceptually quite complex because of the simultaneity of many variables. Most studies avoid much of this computational complexity and instead use fixed allocation rules. But it is difficult (perhaps impossible) to come up with one rule that minimizes taxes for all taxpayers or a set of rules that is consistent with compliant behavior. 
Instead of the tax minimization or empirical methods, we first consider a "resource pooling" method to measure marriage penalties and bonuses. This is also the method used by the Treasury Department's Office of Tax Analysis. As discussed below, this measure is best suited for addressing horizontal equity concerns. We then compare the results of this measure to those obtained using methods that are more similar to the empirical or tax minimization methods used in earlier studies. We find that these alternative measures can be used to address other concerns, such as the impact of marriage penalties and bonuses on family formation and taxpayer compliance.

\section{$\underline{\text { Resource pooling method }}$}

The resource pooling method tries to isolate the effects of a marriage on tax liabilities by assuming that married couples could - through implicit and explicit contractual arrangements duplicate the same pooling of assets and expenses that occurs within their marriages without actually being married. The couple is assumed to live together even if they were not married. Both spouses are assumed to contribute to the family's expenses based on their ability to pay. We measure ability to pay using each spouse's share of gross income. In addition, taxpayers are assumed to both act honestly and understand the tax laws (at least as well as they currently comply with and understand the tax laws). Because the couple is assumed to act similarly whether married or unmarried, this measure provides insight into the effects of marriage penalties and bonuses on horizontal equity.

A brief discussion of the specific assumptions used to allocate dependents and income follows; a more detailed discussion can be found in Bull, Holtzblatt, Nunns, and Rebelein (1999)..$^{5}$ 
Living arrangements: Current law allows only one taxpayer (if otherwise eligible) to claim head of household filing status for a household. This means that at most one taxpayer would be allowed to claim head of household filing status if the couple continues to share a residence and pool resources. To qualify as a head of household, the taxpayer must provide over half the costs of maintaining the home shared with the taxpayer=s children or dependents. While tax return data do not contain much information regarding expenditures on the household or family, it seems reasonable to assume that the individual with the highest income is responsible for most of the costs of maintaining the home and is thus able to claim head of household filing status. Further, we assume this individual is also most likely to provide over half the support for the couple $=\mathrm{s}$ dependents and can thus claim the exemptions. The spouse with the lower income claims single filing status.

Following the rules described earlier for cohabiting couples, we also assume that only the taxpayer with the higher adjusted gross income may claim the EITC when children are present. If there are no children, then current law allows both spouses, if eligible, to claim the EITC if they file as single taxpayers.

Division of earned income and certain transfers: Our measure, like most measures of marriage penalties and bonuses, assumes that returns to human capital are retained by the earner. While some studies have shown that the labor supply of wives is particularly sensitive to marginal tax rates, these second-order effects are generally not accounted for in measures of marriage penalties and bonuses and are not included in our estimates.

Information from Forms W-2s and the Schedules SE are used to allocate wages and selfemployment income to the appropriate earner. We also use information reports (SSA-1099s) from the Social Security Administration to attribute social security and disability insurance 
benefits to the appropriate beneficiary. Unemployment benefits, and miscellaneous forms of earned income, are assumed retained by the earner.

Some deductions and adjustments can only be incurred if the taxpayer has wage or selfemployment income. These include deductions for Keogh contributions, self-employment taxes, self-employment health insurance, and moving expenses. Allocation of these items depends on the spouse's share of self-employment earned income (or, in the case of moving expenses, earned income).

Division of unearned income: Unearned income is divided in proportion to each spouse $=\mathrm{s}$ share of earned income. ${ }^{6}$ The assumption regarding the ownership of assets may also affect the division of other itemized deductions or adjustments. We assume most expenses included in itemized deductions or adjustments are allocated according to ability to pay, and that for this purpose gross income is the appropriate proxy for ability to pay. Changes in the definition of gross income therefore affect the allocation of these deductions and adjustments. Marriage penalties and bonuses using resource pooling method

In 2000 , of the 50.4 million joint returns expected to be filed, 24.4 million ( 48.3 percent) will have a marriage penalty from the individual income tax, 21.1 million (41.9 percent) will have a marriage bonus, and the remaining 5.0 million ( 9.8 percent), many of whom have no tax liability, will have neither a penalty nor bonus (see Table 1). Aggregate marriage penalties in 2000 will be $\$ 30.0$ billion, and aggregate marriage bonuses will be $\$ 28.5$ billion. On net, there will be a marriage penalty of $\$ 1.5$ billion.

The second set of columns in Table 1 contains estimates of marriage penalties and bonuses for all individual income tax provisions except for the EITC. To obtain these estimates, we assume that, as unmarried filers, the couple would be entitled to the same EITC as they 
receive when they file a joint return. ${ }^{7}$ Under this measure, there would be 22.5 million joint filers (44.6 percent) with a marriage penalty, 21.8 million (43.3 percent) who will have a marriage bonus, and 6.1 million (12.1 percent) with neither. Aggregate marriage penalties in 2000 would be $\$ 26.9$ billion, while aggregate marriage bonuses would be $\$ 28.9$ billion. On net, there would be a marriage bonus - not a marriage penalty - of $\$ 2.0$ billion.

The third set of columns in Table 1 shows the difference between the first two sets, which is the contribution of the design of the EITC to marriage penalties and bonuses. The EITC increases the number of couples with marriage penalties by 1.9 million, while reducing the number of couples with marriage bonuses by 710,000 . The number of couples with neither a penalty nor bonus falls by 1.2 million. The EITC adds $\$ 3.1$ billion to aggregate marriage penalties (about 10.4 percent of total penalties), while reducing aggregate marriage bonuses by $\$ 439$ million (or about 1.5 percent of total bonuses). Thus, net aggregate marriage penalties increase by $\$ 3.6$ billion due to the design of the EITC.

The EITC affects marriage penalties and bonuses differently over the income distribution. For couples with positive adjusted gross income (AGI) below $\$ 15,000$ (including the entire phase-in range as well as the plateau and portions of the phase-out range), the EITC increases marriage bonuses by $\$ 144$ million while reducing marriage penalties by $\$ 90$ million. For those with AGI between $\$ 15,000$ and $\$ 30,000$ (covering much of the phase-out range of the EITC), the credit increases marriage penalties by $\$ 1.3$ billion and reduces marriage bonuses by $\$ 191$ million. But most of the effect of the EITC on marriage penalties and bonuses occurs at incomes above the cut-off for EITC eligibility. For couples with AGI between $\$ 30,000$ and $\$ 50,000$, the EITC causes marriage penalties to increase by $\$ 1.6$ billion and marriage bonuses to fall by $\$ 219$ million. In total, nearly 55 percent of EITC-related marriage penalties will be attributable to 
couples whose incomes are between $\$ 30,000$ and $\$ 60,000$. The EITC has a negligible effect on marriage penalties and bonuses at higher income levels since the higher-earner spouse's income must be less than $\$ 31,000$ to qualify for the EITC as an unmarried filer.

Table 2 looks at marriage penalties and bonuses among EITC claimants only. In total, about one in four EITC claimants currently file a joint return. Among the 4.6 million EITC claimants filing jointly in 2000, 1.4 million (30.1 percent) will have a marriage penalty, 1.3 million (28.7 percent) will have a marriage bonus, and the remaining 1.9 million (41.2 percent), most of whom are one-earner couples, will have neither. Aggregate marriage penalties in 2000 will be $\$ 1.2$ billion (4.1 percent of aggregate marriage penalties for all filers), and aggregate marriage bonuses will be $\$ 554$ million (1.9 percent of aggregate marriage bonuses for all filers). EITC claimants would experience net marriage penalties of $\$ 682$ million.

The EITC increases the total number of credit claimants with marriage penalties by 1.1 million, while reducing the number with bonuses by over 100,000 and the number with neither a penalty nor bonus, many of whom are one-earner couples, by 1 million. For EITC claimants, the EITC is responsible for nearly all $-\$ 1.2$ billion or 94.1 percent - of aggregate marriage penalties caused by the individual income tax. Nonetheless, a comparison of the findings in Tables 1 and 2 shows that nearly 63 percent of EITC-related marriage penalties are attributable to couples who do not qualify for the EITC as joint filers because their combined income exceeds the eligibility cut-off. Not surprisingly, marriage penalties among EITC claimants are primarily found amongst those with AGI between $\$ 15,000$ and $\$ 30,000$. Table 2 also shows that the EITC increases aggregate marriage bonuses among claimants by only $\$ 31$ million (5.6 percent). Marriage bonuses among credit claimants with AGI below $\$ 15,000$ are also largely attributable to the EITC. 
As shown in Table 3, only two-earner couples have marriage penalties. ${ }^{8}$ Further, the effect of the EITC on marriage penalties and bonuses is generally concentrated among twoearner couples. These results reflect the assumptions, in the resource pooling model, that the higher earner would claim the children if the two spouses filed separate returns.

Estimates of marriage penalties and bonuses under alternative assumptions

Separate residences: Under this alternative, we assume each spouse maintains a separate residence. This method measures the penalty or bonus associated with two decisions: the decision to marry and the decision to share a residence. It may be a more appropriate measure than the joint residence method when considering the impact of the EITC or other tax provisions on the decisions to separate or divorce, net of other factors (such as the costs of maintaining two residences) (Holtzblatt, 1997).

When assuming separate residences, tax law alone does not provide guidance as to which spouse might be eligible to claim dependents or file as head of household. For purposes of this measure, we assume the lower-earner spouse becomes the custodial parent and claims head of household filing status, the dependents, and the EITC. These assumptions are similar to those used by Alm and Whittington for allocating dependents under their empirical approach, since the lower-earner spouse tends to be the wife. Alm and Whittington (1999), Dickert-Conlin (1999), and Eissa and Hoynes (1999) also use similar assumptions when examining the effects of the EITC or tax system on family formation decisions.

This alternative method results in an aggregate net marriage bonus of $\$ 27.2$ billion, in contrast to the $\$ 1.5$ billion net marriage penalty under our first measure (Alternative 1 in Table 4). While aggregate marriage penalties are only $\$ 1.1$ billion larger $(\$ 31.1$ billion under the separate residences method vs. $\$ 30.0$ billion under the resource sharing method), aggregate 
marriage bonuses ( $\$ 58.3$ billion) are more than twice those found using the resource pooling method. The large difference in marriage bonuses occurs because the head of household status, exemptions, and child-related credits generally provide less benefit to the lower-earner spouse than to the higher-earner spouse (who is often in a higher tax bracket and has greater tax liability to absorb credits). ${ }^{9}$

Under this alternative method, the EITC will increase marriage penalties by $\$ 9.9$ billion and reduce marriage bonuses by $\$ 5.7$ billion in 2000 . Net penalties will increase by nearly $\$ 15.6$ billion. The EITC is responsible for a greater share of both marriage penalties and bonuses than under the resource pooling method: 31.7 percent of total marriage penalties instead of 10.4 percent, and 9.8 percent of total marriage bonuses instead of 1.5 percent.

The choice of assumptions also affects the distribution of the marriage penalties and bonuses attributable to the EITC. Under the separate residency assumption, the EITC increases marriage bonuses by $\$ 3.5$ billion and has a negligible effect on marriage penalties for couples with AGI below $\$ 15,000$. This is largely the effect of nonworkers (or very low-earners) with children marrying workers with earnings within the EITC range. For couples with AGI between $\$ 30,000$ and $\$ 50,000$, the EITC increases marriage penalties by $\$ 4.6$ billion and reduces marriage bonuses by $\$ 3.1$ billion. Among those with AGI above $\$ 50,000$ (a group largely unaffected by the EITC under the resource pooling method), marriage penalties increase by $\$ 4.3$ billion as a consequence of the EITC, while marriage bonuses fall by $\$ 7.8$ billion.

The magnitude of the EITC's effect on marriage penalties and the distributional results reflect the assumption that the lower-earner spouse could qualify for an EITC if his or her income is not combined with the income of a high earning spouse. Under this method, couples 
with combined incomes that exceed $\$ 60,000$ could incur an EITC-related marriage penalty as long as the lower earning spouse's income was less than $\$ 31,000$.

Under this alternative, 3.8 million (83.4 percent) couples claiming the EITC will have marriage bonuses, and the amount of total marriage bonuses will be $\$ 9.9$ billion (see Table 5). Only 583,000 couples (12.8 percent) claiming the EITC will have a marriage penalty, and the aggregate amount of marriage penalties is $\$ 650$ million. With relatively few EITC claimants incurring a marriage penalty due to the credit, over 93 percent of EITC-related marriage penalties under this measure are accrued by couples whose combined income is too high to qualify for the credit as joint filers. On net, EITC claimants are estimated to have $\$ 9.3$ billion of marriage bonuses, of which nearly half $-\$ 4.7$ billion - is attributable to the EITC.

Minimizing tax liability by changing the allocation of children: As discussed earlier, it is difficult to derive assumptions that would minimize taxes for all couples if they filed as unmarried, but still be consistent with compliant behavior and be computationally simple. Under this alternative, we allow couples to allocate dependents, but not income and expenses, in the manner that would minimize their combined income tax liability when filing separate returns without being constrained by the rules governing dependency, household maintenance, or the residency of EITC qualifying children. As a result, the dependents may be claimed by either spouse or divided between them, and both spouses are allowed to claim head of household filing status if eligible. Both may claim the EITC (even if children are present), and they may each claim up to two EITC qualifying children.

This method is consistent with either one of the following scenarios. Under the first scenario, a couple divorces, and the former spouses move into separate residences. They divide custody of their children and other dependents in the manner that minimizes their combined 
separate income tax liabilities. Under the second scenario, they do not divorce. However, they do not comply (either intentionally or unintentionally) with the tax code provisions governing dependents, filing status, and EITC qualifying children. Instead, they claim to be unmarried and living separately. Under this scenario, the alternative does not measure marriage penalties and bonuses under current law but may, instead, be an estimate of what some married couples perceive their penalties or bonuses to be without fully understanding how tax laws would actually apply if they were not married.

These alternative assumptions do not affect the tax liability for 24 million couples who do not have dependents. Among the remaining 26.5 million couples, 14.7 million (55.4 percent) would minimize taxes when filing separate returns by allocating all of the dependents to the higher earner, 7.5 million (28.4 percent) would minimize taxes by somehow splitting the child dependents, and 4.3 million (16.1 percent) would fare better under the income tax system if the lower-earner spouse could claim all of the dependents. ${ }^{10}$ Nearly half (49.1 percent) of those who benefit by splitting dependents or allocating them to the lower earner have AGI below $\$ 60,000$.

Under this alternative, 26.8 million (53.1 percent) couples would have a marriage penalty, 19.3 million (38.2 percent) would have a marriage bonus, and 4.4 million ( 8.7 percent) would have neither a penalty nor bonus (Alternative 2 in Table 4). Couples would incur a total of $\$ 42.9$ billion of marriage penalties and $\$ 27.0$ billion of marriage bonuses. On net, there would be a total of $\$ 15.9$ billion of marriage penalties.

Assuming couples could receive the same total EITC as unmarried filers as they would receive as joint filers dramatically affects the benefits to reallocating children between the spouses. Over three-quarters of couples with dependents (20.1 million) would minimize their 
combined income tax liability if the higher-earner spouse claimed the dependents. The number who benefit from splitting their dependents falls by 2.3 million to 5.3 million, while the number who minimize income tax liability by allocating dependents to the lower-earner spouse declines by 3.2 million to 1.1 million. Among those who split dependents or allocate them to the lower earner, nearly two-thirds have AGI above $\$ 60,000$. Even though the dependent exemptions would be valued at a higher marginal tax rate, higher income taxpayers may benefit from shifting dependents because of the phase-out of the dependent exemption, the alternative minimum tax, and the "kiddie" tax.

Under this alternative, the EITC will increase aggregate marriage penalties by $\$ 12.8$ billion (29.7 percent of aggregate penalties), while total marriage bonuses will be reduced by $\$ 1.5$ billion (5.7 percent of aggregate bonuses) in 2000. On net, the EITC will increase marriage penalties by $\$ 14.3$ billion.

Thus, the effects of the EITC on total marriage penalties are greatest when taxpayers are assumed able to reorganize their actual or reported living arrangements so as to minimize their combined tax liabilities as unmarried individuals. Under this alternative, they can choose to allocate their children in the way that will result in the lowest income tax liability. For example, many two-earner couples would find it advantageous to allocate the children to the lower earner if the higher earner's income is in the EITC phase-out range or higher and both spouses are in the 15 percent rate bracket (i.e., the value of most other child tax benefits is the same regardless of which spouse claims the children). As tax-minimizers, couples also have a choice that is not available to them under the resource sharing or separate residence alternatives: by splitting custody of their children, each spouse can claim the EITC if they were not married, thus increasing the magnitude of EITC-related marriage penalties. 
This alternative measure also affects the distribution of marriage penalties and bonuses. In contrast to the resource pooling method, the EITC increases marriage penalties by more than marriage bonuses among those with AGI below $\$ 15,000$. Marriage penalties increase by $\$ 2.3$ billion among joint filers with AGI between $\$ 15,000$ and $\$ 30,000$, or $\$ 959$ million more than under the resource pooling method. The most significant differences occur among joint filers with AGI between $\$ 30,000$ and $\$ 100,000$, where marriage penalties increase by $\$ 9.7$ billion, or $\$ 8.0$ billion more than under the resource pooling method.

Among EITC claimants, the number of taxpayers with marriage penalties and bonuses is similar to those under the resource pooling method. However, aggregate marriage penalties, and the amount attributable to the EITC, will be nearly $\$ 1$ billion higher under this alternative (see Table 5). Further, these results, in combination with the findings in Table 4, imply that a greater share (over 83 percent) of EITC-related marriage penalties are attributable to couples who do not qualify for the credit as joint filers than under the resource pooling method.

Unearned income evenly divided: Splitting unearned income evenly tends to equalize spouses' income. This, in turn, increases marriage penalties and reduces marriage bonuses relative to assumptions that allocate unearned income in proportion to earned income. When unearned income is assumed to be divided evenly if the couple were not married, there would be $\$ 38.9$ billion of marriage penalties and \$20.6 billion of marriage bonuses (Alternative 3 in Table 4).

Assumptions regarding the allocation of unearned income do not significantly change the effect of the EITC on marriage penalties and bonuses relative to resource pooling method. The EITC will reduce marriage penalties by $\$ 3.3$ billion, or by $\$ 209$ million more than under the resource pooling method, and will reduce marriage bonuses by $\$ 387$ million, or by $\$ 52$ million 
less than under the resource pooling method. Among credit claimants, the EITC will reduce marriage penalties by $\$ 1.2$ billion, or by $\$ 35$ million more than under the resource pooling method (see Table 5).

\section{Analysis of Recent Proposals to Reduce Marriage Penalties in the EITC}

Over the past two years, both the Clinton Administration and Congress have introduced proposals that would reduce marriage penalties caused by the standard deduction, rate brackets, and the EITC. In this section, we consider the impact of several Congressional proposals to reduce marriage penalties in the EITC using the resource pooling method.

Increase EITC Phase-out Range by $\$ 2,000$

In 1999, Congress passed the "Taxpayer Refund and Relief Act of 1999," which was subsequently vetoed by President Clinton. Under this bill, the starting point of the EITC phaseout range would be extended by $\$ 2,000$ for married couples filing joint returns beginning in 2006. Because the phase-out rate would not be changed, the EITC would phase out at income levels that are $\$ 2,000$ higher than under current law. The $\$ 2,000$ amount would be adjusted for inflation after 2006. (All proposals are evaluated at calendar year 2000 levels. At 2000 levels, the EITC phase-out range would be extended by $\$ 1,740$.)

Example: A married couple with two children earns $\$ 30,000$ in 2000 . Both spouses work. One spouse earns $\$ 18,000$, and the other receives $\$ 12,000$. They have no other forms of income. Under current law, they receive an EITC of $\$ 243$ and pay income taxes of $\$ 475$. Their marriage penalty (both as a result of the EITC and other factors) is $\$ 2,525$.

Under the proposal, their EITC would increase by $\$ 366$ to $\$ 609$, and their income taxes would fall to $\$ 109$. Their marriage penalty would also drop by $\$ 366$ to $\$ 2,159$. 
Effects: At a cost of $\$ 1$ billion a year, the proposal would primarily benefit low and moderate-income taxpayers (see Table 6). At 2000 levels, 3.6 million couples would have an average tax cut of $\$ 275$, with nearly all of the benefits (93.2 percent) going to couples with AGI below $\$ 30,000$ who are already eligible for the EITC. About 500,000 taxpayers would become eligible for the EITC.

Less than half ( $\$ 406$ million or 40.6 percent) of the benefits of the proposal would reduce marriage penalties. Of the 3.6 million couples who would benefit from the proposal, one-third would receive a larger bonus than under current law, and nearly one-fourth, who currently do not have either a bonus or penalty, would receive a bonus. The proposal would also add some complexity to the current EITC instructions, by adding several columns to look-up tables and a few additional lines to the instructions.

An examination of two variants of the Congressional proposal illustrates the trade-off between two tax policy goals: marriage neutrality and tax simplicity. In the first variant, a greater share of the costs of the proposal could be used to reduce marriage penalties by limiting the expansion to couples where both spouses earn at least \$2,000 (Proposal 1a in Table 6). This would reduce the costs of the proposal by over 60 percent (to $\$ 394$ million a year), with $\$ 366$ million (or 92.9 percent of the costs) reducing marriage penalties. While this proposal would be more efficient than the Congressional proposal in reducing marriage penalties, it would be more complicated and difficult for the IRS to verify eligibility during initial return processing because spouses' wage and salary incomes are not shown separately on tax returns. (Sometime later in the year after refunds are paid out, the IRS would be able to verify each spouse's share of earned income using the edited and matched Forms W-2.) 
The second variant would extend the plateau by $\$ 2,000$ for all taxpayers (Proposal $1 \mathrm{~b}$ in Table 6). Unlike the preceding two options, this variant would not require any fundamental changes to the tax instructions or forms. Taxpayers would determine their eligibility for the EITC and compute the amount of the credit using tax forms and look-up tables that look identical to those they currently use, except for containing higher credit amounts. But this option is costlier and provides no relief for marriage penalties. It would cost three times as much $(\$ 3.2$ billion a year) and provide tax cuts to 2.4 million single filers and 7.1 million heads of households as well as the 3.6 million couples covered by the Congressional proposal. It would increase aggregate marriage penalties by $\$ 685$ million, while reducing aggregate marriage bonuses by $\$ 95$ million.

Increase EITC Phase-out Range by $\$ 3,500$

During consideration of the tobacco bill in 1998, Senator Phil Gramm (R-Texas) offered an amendment that would, among other things, allow married taxpayers to deduct $\$ 3,500$ of income in the phase-out range of the EITC (Proposal 2 in Table 6). This proposal effectively increases the beginning and end-points of the phase-out range by $\$ 3,500$, which is equal to the difference between the standard deduction for a couple filing a joint return and the combined standard deduction for a single filer and a head of household. This amount was chosen because the amendment also provided all joint filers with income below $\$ 50,000$ with an additional deduction of the same amount. The analysis below considers only the effects of the EITC expansion.

Example: For the two-earner couple described above, the proposal would increase their EITC by $\$ 737$ to $\$ 980$. On net, they would receive a tax refund of $\$ 262$, and their marriage penalty would fall to $\$ 1,788$. 
Effects: This option would cost over $\$ 2$ billion a year, or twice the cost of the conference agreement. Under the option, 4.2 million taxpayers would receive an average tax cut of $\$ 488$. Over 90 percent of the benefits of the option would go to taxpayers with AGI below $\$ 30,000$, with one million couples becoming eligible for the EITC. As with the proposal contained in the 1999 tax bill, only about 38 percent of the benefits of the proposal actually reduce marriage penalties.

\section{Allow Two-Earner Deduction}

Senator Tom Daschle (D-South Dakota) introduced S. 8 in January, 1999. It contains a provision to reinstate the two-earner deduction that had existed prior to the Tax Reform Act of 1986. His bill went further than prior law by extending a two-earner deduction explicitly to the EITC. Under the bill, married couples could deduct 20 percent of the earnings of the lowerearner spouse from income when computing the EITC in the phase-out range. The analysis below examines only the proposed changes to the EITC (Proposal 3 in Table 6).

Example: Under this proposal, the two-earner couple described above would be able to deduct 20 percent of the lower earner's earnings, or $\$ 2,400(.2 * \$ 12,000)$, from income in the EITC phase-out range. As a consequence, the couple's EITC would increase by $\$ 505$ to $\$ 748$, and they would receive a net income tax refund of $\$ 30$. The marriage penalty would fall to $\$ 2,020$.

Effects: At a cost of roughly $\$ 300$ million a year, this proposal would provide 1.6 million couples with an average tax cut of $\$ 192$. Most (87.1 percent) of the benefits would go to couples with AGI under $\$ 30,000$. The rest of the benefits go to couples with AGI between $\$ 30,000$ and $\$ 40,000$. The majority of those who benefit already receive the EITC; the option would extend EITC eligibility to fewer than 200,000 new claimants. 
Over 95 percent of benefits would reduce marriage penalties. Of the 1.6 million couples who would benefit from the proposal, 1.5 million would have a reduction or elimination of their marriage penalties.

We also consider a variant that would allow two-earner couples to deduct 100 percent of the earned income of the lower-earning spouse when computing the EITC (Proposal 3a in Table 6). This option effectively treats married couple in roughly the same manner as if they were single but cohabiting. If they were not married and living in the same residence, the higher earner would generally win the AGI tiebreaker and claim the EITC. The lower earner would not be eligible for any EITC. Under this option, eligibility for the EITC would be based on the earnings of the higher earner, and the earnings of the lower earning spouse would be disregarded entirely for EITC eligibility determinations. ${ }^{11}$

Under this variant, 3.5 million couples would have an average tax cut of $\$ 878$ at a cost of $\$ 3.1$ billion a year. Nearly 88 percent of benefits would reduce marriage penalties. Most (55 percent) of the benefits would go to couples with AGI between $\$ 30,000$ and $\$ 60,000$. The rest of the benefits go to couples with AGI under $\$ 30,000$, with 42.5 percent of benefits accruing to couples with AGI between $\$ 15,000$ and $\$ 30,000$. EITC eligibility would be extended to 2.1 million couples with incomes up to $\$ 60,000$.

A two-earner deduction demonstrates some of the trade-offs between the various goals of the EITC. A two-earner deduction is very well-targeted to reducing marriage penalties. Further, by increasing the return to work, a two-earner deduction may increase labor force participation by the lower-earner spouse, particularly among those already eligible for the EITC. But since only two-earner couples would receive the deduction, the option violates the principle in current law that couples with the same total incomes pay the same total taxes. By extending the EITC 
phase-out range, it also increases marginal tax rates on taxpayers with AGI roughly between $\$ 30,000$ and $\$ 60,000$. Finally, it increases filing burdens by requiring an additional worksheet or form for the computation of the two-earner deduction.

Effects of alternative assumptions on measures of proposals

The bottom half of Table 6 shows the effects of the various proposals under the alternative assumption that the spouses would not live together if they were not married. As shown in Bull, Holtzblatt, Nunns, and Rebelein (1999), the change in the level of aggregate marriage penalties net of bonuses is the same for the proposals that only change the EITC for married couples. Thus, estimates of the change in net marriage penalties are invariant to the assumption used, when measuring the effect of proposals that affect joint filers only. However, the choice of assumptions may affect the allocation between marriage penalties and bonuses.

Moreover, between 1975 and 1999, the credit has never been changed for only joint

filers. When the EITC phase-out range is extended by $\$ 2,000$ for all taxpayers (option 1b), the change in net marriage penalties differs greatly under the two sets of assumptions. Under the resource pooling method, net marriage penalties increase by $\$ 780$ million, while they rise by $\$ 1.2$ billion under the separate residence assumption and by $\$ 1.9$ billion under the tax minimization method. This result follows from the fact that the computation of the EITC changes for both married and unmarried filers under this variant, and the amount received by unmarried filers is sensitive to the assumptions made regarding living arrangement and custody of the children. Studies that examine the effect of comprehensive changes in the income tax, including the EITC, on marriage penalties and bonuses should test the sensitivity of their estimates to alternative measures of marriage penalties and bonuses. 


\section{Conclusions}

Measures of aggregate marriage penalties and bonuses are very sensitive to the underlying assumptions used to allocate a married couple's income, living arrangements, and dependents if they were able to file separate returns. Estimates of marriage penalties and bonuses attributable to the EITC - both in the aggregate and relative to total marriage penalties and bonuses - are also sensitive to the assumptions used to allocate living arrangements and dependents. However, the estimates of EITC-related penalties and bonuses are not very sensitive to the division of unearned income.

Estimates of EITC-related marriage penalties and bonuses are smallest under the assumption that the couple would continue to live together if they were not married. This is not surprising because the EITC eligibility rules effectively reduce marriage penalties and bonuses among married and unmarried couples who are the most similar - those who live together with their children. Using this measure, we find that the EITC will increase total marriage penalties by $\$ 3.1$ billion (10.4 percent) and reduce total bonuses by $\$ 439$ million (1.5 percent) in 2000 . Among those who claim the EITC, the credit will increase marriage penalties by $\$ 1.1$ billion and will account for nearly all - about 94 percent - of the marriage penalties imposed by the individual income tax on these taxpayers. However, couples who currently are ineligible for the EITC will incur nearly 63 percent of EITC-related marriage penalties because their combined income exceeds current law eligibility limits. Over half of EITC-related marriage penalties will be attributable to couples who are ineligible because their income is over $\$ 30,000$.

This measure provides the best estimate of marriage penalties and bonuses when considering the effect of the EITC on horizontal equity - the relative tax treatment of couples who are similar in all ways, except for the presence of a marriage license. Other measures of 
marriage penalties and bonuses may be better suited for studying the effect of the EITC on family formation decisions or tax avoidance or evasion. Under these alternative measures, the EITC is found to increase marriage penalties by between $\$ 9.9$ billion and $\$ 12.8$ billion and reduce marriage bonuses by between $\$ 1.5$ billion and $\$ 5.7$ billion. Regardless of the assumptions used to allocate family responsibilities or income, the EITC is responsible for most of the income tax-related marriage penalties among EITC claimants, while most EITC-related marriage penalties are attributable to higher-income taxpayers who are currently not eligible for the EITC.

Recent proposals to reduce EITC marriage penalties are well-targeted to lower-income taxpayers. Proposals that would extend the length of the EITC phase-out range for married couples are relatively simple to administer, but less than half of their costs go to the reduction of marriage penalties. A two-earner deduction would be a more target-efficient way of reducing EITC-related marriage penalties, but would add some complexity to the EITC schedule and instruction.

But most recent proposals eliminate only a small portion of total marriage penalties attributed to the EITC. It is not possible to eliminate all marriage penalties attributable to the EITC unless eligibility is extended to couples with incomes of $\$ 60,000$ (or more, depending on the assumptions used to measure marriage penalties). But in the past, there has been some resistance (from both sides of the political spectrum) to expanding the EITC to more middleincome families rather than targeting additional assistance to those with lower incomes, many of whom are headed by a single parent or by a one-earner couple (Ventry, 1999).

Does this mean that the current proposals do not address concerns caused by EITCrelated marriage penalties and bonuses? Although most EITC-related marriage penalties are 
incurred by higher income taxpayers, the EITC is responsible for most of the marriage penalties experienced by low-income couples as a result of the individual income tax. Targeting lowerincome families may also have indirect effects that are not observed in our sample of married couples. About three-quarters of EITC claimants are not counted as incurring a marriage penalty precisely because they are unmarried. If the EITC affects marriage decisions, reducing the credit's marriage penalties or increasing its marriage bonuses may affect family formation decisions among these single individuals in ways that policymakers view as beneficial. However, the evidence of the effect of the EITC on marriage is mixed, and the results of prior studies may be sensitive to their specification of marriage penalties and bonuses. Further research on the effect of the EITC on family formation decisions should take into account all of the ways - such as the AGI tiebreaker and the abandoned spouse rules - in which the tax code distinguishes among families.

\section{ENDNOTES}

This paper was prepared for a conference entitled, "The Earned Income Tax Credit: Early Evidence," at the Joint Center for Poverty Research, Northwestern University, on October 7-8, 1999. The authors especially thank Bob Gillette for his guidance. We also thank Len Burman, Lowell Dworin, Doug Holtz-Eakin, Marvin Kosters, Janet McCubbin, Bruce Meyers, Jim Nunns, Karl Scholz, Eric Toder, and anonymous referees for their very helpful comments. Views and opinions expressed in this paper are those of the authors and do not necessarily represent the policies or positions of the Department of the Treasury.

1 In 1996, GAO identified 59 provisions in the income tax code that created marriage penalties and bonuses. Since the publication of the GAO report, the number of provisions that are not neutral with respect to marriage has likely increased. These would include a number of provisions enacted in the Taxpayer Relief Act of 1997, including the child tax credit, educational credits, and Roth individual retirement accounts.

2 In many other countries, the individual is the filing unit for the income tax, and each spouse is taxed on his or her own income. As a result, the individual's tax liability does not generally change upon marriage in these countries. However, the United Kingdom has recently adopted an EITC-like tax credit (the "Working Family Tax Credit") that is based on the couple's combined income, even though the individual is still the unit of taxation for the rest of the income tax. 
3 There may be differences in ability to pay between two-earner and one-earner couples because the monetary value of the services, such as child care, provided by the stay-at-home spouse is not taxed. Through the child and dependent care tax credit and the exclusion for child and dependent care, the tax code adjusts for differences in ability to pay caused by work-related child care expenses. Married couples generally cannot claim the credit unless both spouses work, and they incur child care costs in order to work.

4 Other types of households may also be affected by the AGI tiebreaker test. The AGI tiebreaker applies whenever a child satisfies the EITC relationship and residency tests with respect to more than one taxpayer. Under the relationship test, the child must be the taxpayer's son, daughter, grandchild, or foster child. Under the residency test, the taxpayer must reside with the child for over six months (12 months if the child is the taxpayer's foster child). Thus, a threegeneration household - child, mother, and grandmother, for example - could also be affected by the AGI tiebreaker. If a single mother lived with both her child and her mother, and her mother had the higher AGI, then only the grandmother could claim the EITC with respect to the child. The test may also apply when an unrelated individual shares a home with a parent and child, but newly enacted legislation limits the circumstances under which this may occur. Under pre-2000 law, a live-in boyfriend might have been eligible to claim his girlfriend's child from a previous relationship as his foster child if the boyfriend lived with the child for the full year and cared for the child as his own. In late 1999, Congress passed legislation to modify the definition of a foster child. Under this provision, a taxpayer will not be able to claim a child as a foster child unless the taxpayer (a) is the sibling or aunt or uncle of the child or the child has been placed in the taxpayer's home by an authorized placement agency; (b) cares for the child as his or her own; and (c) lives with the child for a full year.

5 Our estimates are based on current law as of September 24, 1999. In late 1999, Congress enacted legislation to prevent the alternative minimum tax (AMT) from reducing personal credits, including the child credit and the child and dependent care tax credit, in tax years 2000 and 2001. Our estimates do not reflect this temporary provision.

6 Tax return information could be used to directly allocate certain other forms of unearned income to each spouse. However, even pensions may be considered a marital asset that should be divided when the marriage ends.

7 This approach allows us to isolate the effects of the design of the EITC on marriage penalties and bonuses. It is consistent with our overall approach of estimating the marriage penalties and bonuses associated with the structural design of the individual income tax. We assume the continued existence of the income tax, and specifically the EITC, in the second step. Because of the interactions between the EITC and the $\$ 500$ child tax credit, our results would have been qualitatively and quantitatively different had we assumed that the EITC did not exist in this step. For families with three or more children, the full amount of the child tax credit depends on the taxpayer's EITC, as well as their income and payroll tax liabilities. Under the approach taken in our paper, the measure of the effect of the EITC on marriage penalties reflects some changes in the child tax credit, but only to the extent that the EITC would change if the couple could file as unmarried individuals rather than filing a joint return. If we instead had assumed that the EITC 
did not exist, our estimates would include some changes in the child credit resulting solely from the repeal of the EITC. This is because the couple's child tax credit changes as a consequence of the repeal of the EITC, even if they file a joint return.

8 Two-earner couples are defined to include couples where one or both spouses have social security or unemployment compensation benefits.

$9 \quad$ All other things equal, the existence of such large marriage bonuses might discourage separations and divorce. Our measure does not account for second-order changes, including the change, if any, in marital behavior that might occur in response to the presence of such large marriage bonuses.

10 Some taxpayers whose taxes are minimized by splitting custody of the children would fare equally well if they allocated all children to the lower-income spouse.

11 There are a number of other ways that a single filing option could be designed. Senator Daniel Moynihan (D-NY) recently proposed that each spouse would be able to claim the EITC based on their own income, and that they each be allowed to claim up to two children in the family. Senator Moynihan's proposal effectively treats a married couple as if they were living apart and had divided custody of their children. 


\section{REFERENCES}

Alm, James, and Leslie A. Whittington. "For Love or Money? The Impact of Income Taxes on Marriage." Economica 66 (August, 1999): 297-316.

Alm, James, and Leslie A. Whittington. AIncome Taxes and the Timing of Marital

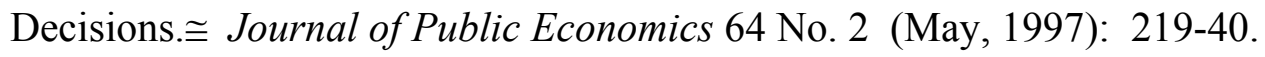

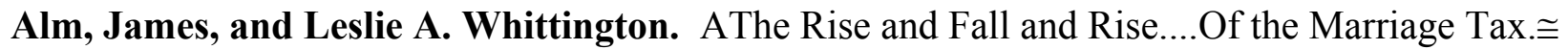
National Tax Journal. 49 No. 4 (December, 1996): 571-89.

Bittker, Boris I. "Federal Income Taxation and the Family." Stanford Law Review. 27 (July, 1975): 1389-463.

Brazer, Harvey E. "Income Tax Treatment of the Family." In The Economics of Taxation, edited by Henry J. Aaron and Michael J. Boskin, 223-46. Washington, D.C.: Brookings Institution, 1980.

Bull, Nicholas, Janet Holtzblatt, James R. Nunns, and Robert Rebelein. "Defining and Measuring Marriage Penalties and Bonuses." OTA Paper No. 82. Washington, D.C.: U.S. Department of the Treasury, 1999.

Dickert-Conlin, Stacy. "Taxes and Transfers: Their Effects on the Decision to End a Marriage.” Journal of Public Economics. 73 (August, 1999): 217-40.

Dickert-Conlin, Stacy, and Scott Houser. ATaxes and Transfers: A New Look at the Marriage Penalty. National Tax Journal. 51 No. 2 (June, 1998): 175-217.

Eissa, Nada and Hilary Williamson Hoynes. "Good News for Low Income Families? TaxTransfer Schemes and Marriage.” University of California, Berkeley. Mimeo, 1999.

Ellwood, David T. "The Impact of the Earned Income Tax Credit and Social Policy Reforms on Work, Marriage, and Living Arrangements." Paper presented at a conference entitled, "Earned Income Tax Credit: Early Evidence," Northwestern University. October, 1999.

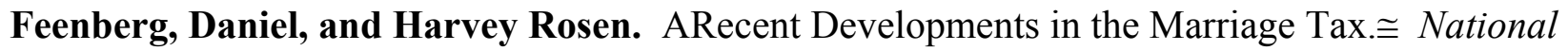
Tax Journal 48 No. 1 (March, 1995): 91-101.

Holtzblatt, Janet. AComments on Taxes and Transfers: Their Effects on the Decision to End a Marriage. In Proceedings of the Eighty-Ninth Annual Conference on Taxation. 306-7. Washington, D.C.: National Tax Association - Tax Institute of America, 1997.

McCubbin, Janet. "EITC Noncompliance: The Misreporting of Children and the Size of the EITC." Paper presented at a conference entitled, "Earned Income Tax Credit: Early Evidence," Northwestern University. October, 1999. 
Rosen, Harvey. AThe Marriage Tax Is Down But Not Out. National Tax Journal 40 No. 4 (December, 1987): 567-75.

Scholz, John Karl, Deputy Assistant Secretary for Tax Analysis, U.S. Department of the Treasury. Testimony before the U.S. House of Representatives, Committee on Ways and Means. Washington, D.C., May 8, 1997.

U.S. Congressional Budget Office. For Better or Worse: Marriage and the Federal Income Tax. Washington, D.C., June, 1997.

U.S. General Accounting Office. Income Tax Treatment of Married and Single Individuals. GAO/GGD-96-175. Washington, D.C.: Government Printing Office, 1996.

Ventry, Dennis J., Jr. "The Collision of Tax and Welfare Politics: The Political History of the EITC, 1969-99." Paper presented at a conference entitled, "Earned Income Tax Credit: Early Evidence,” Northwestern University. October, 1999. 



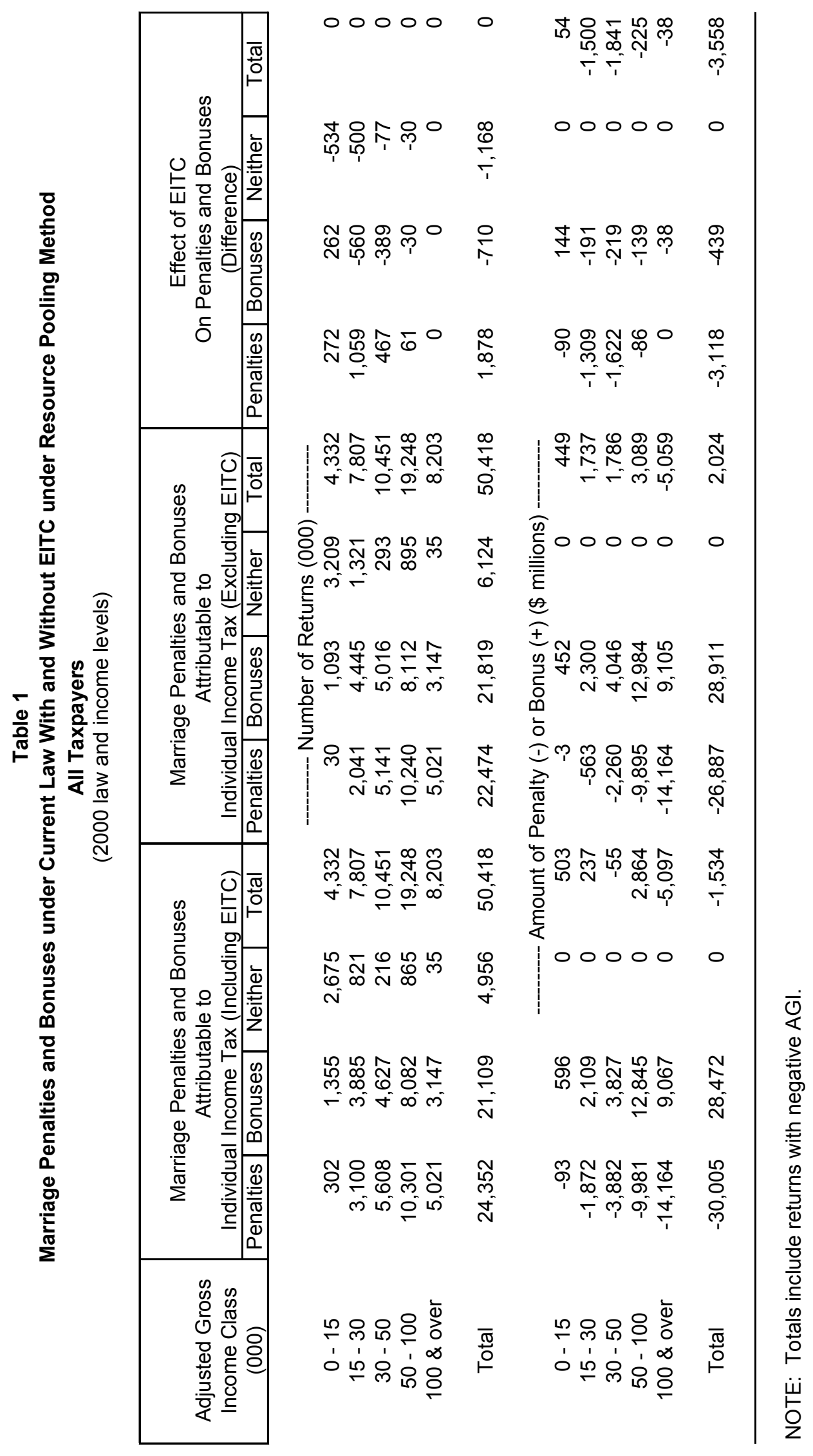




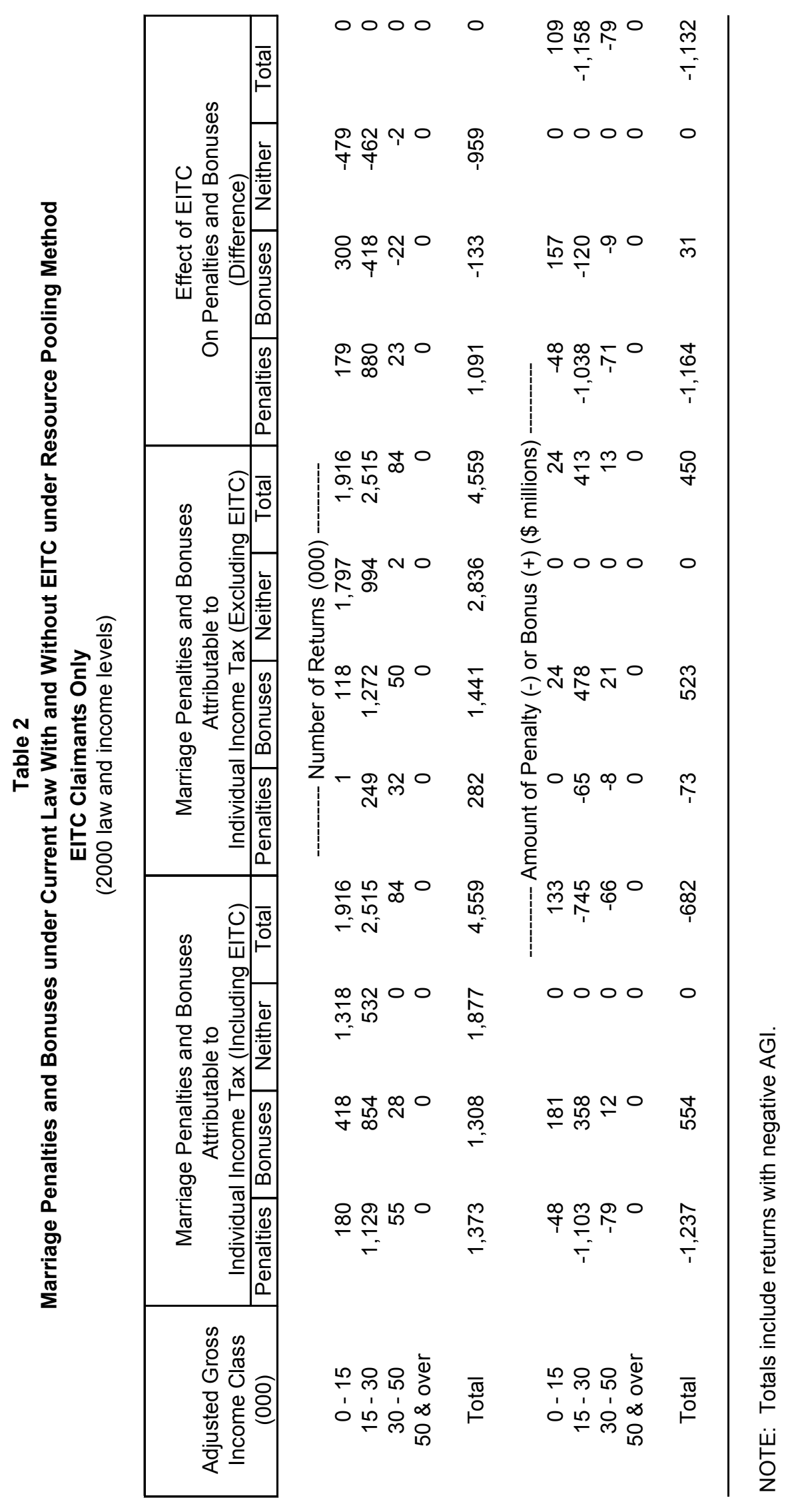




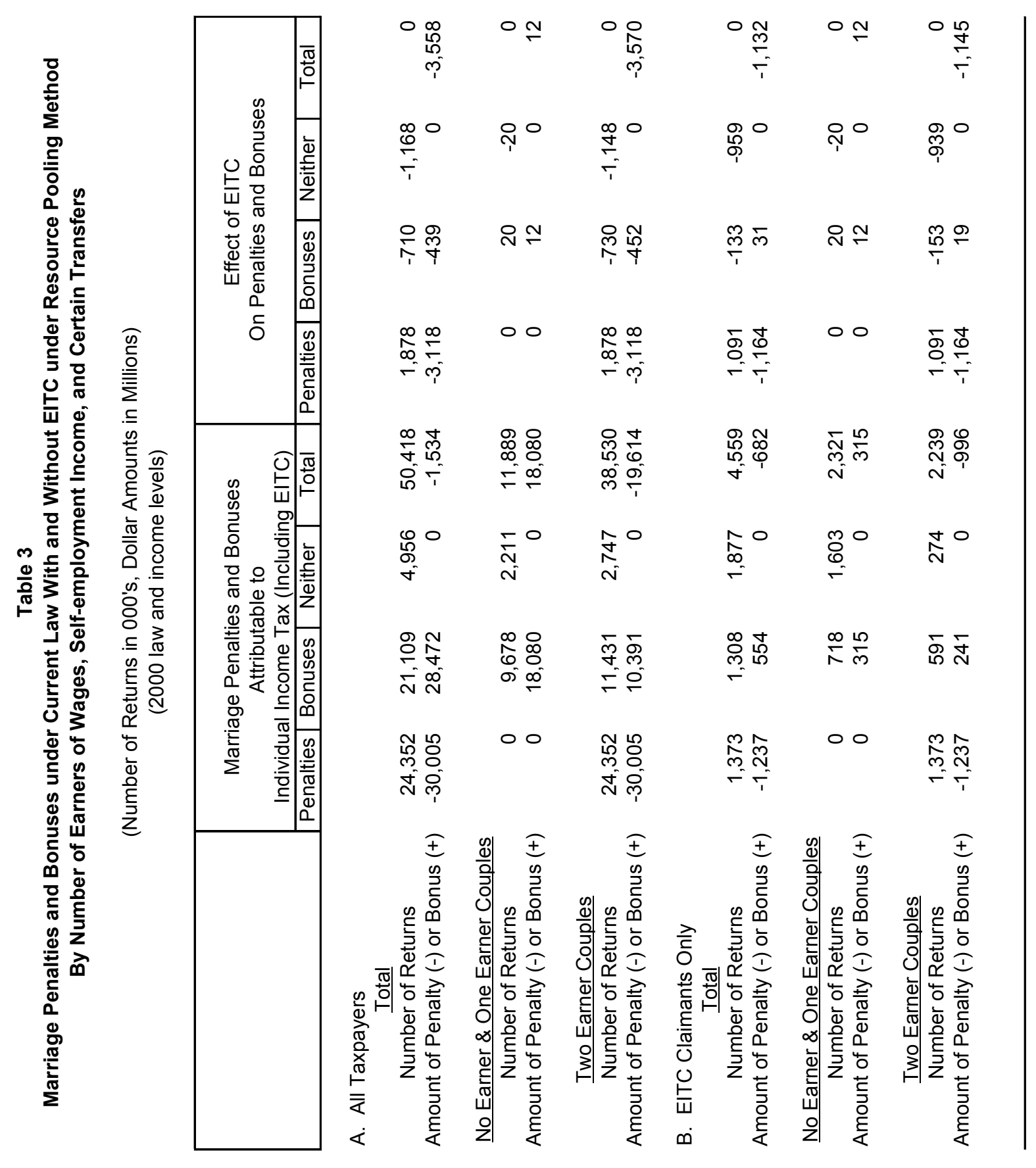




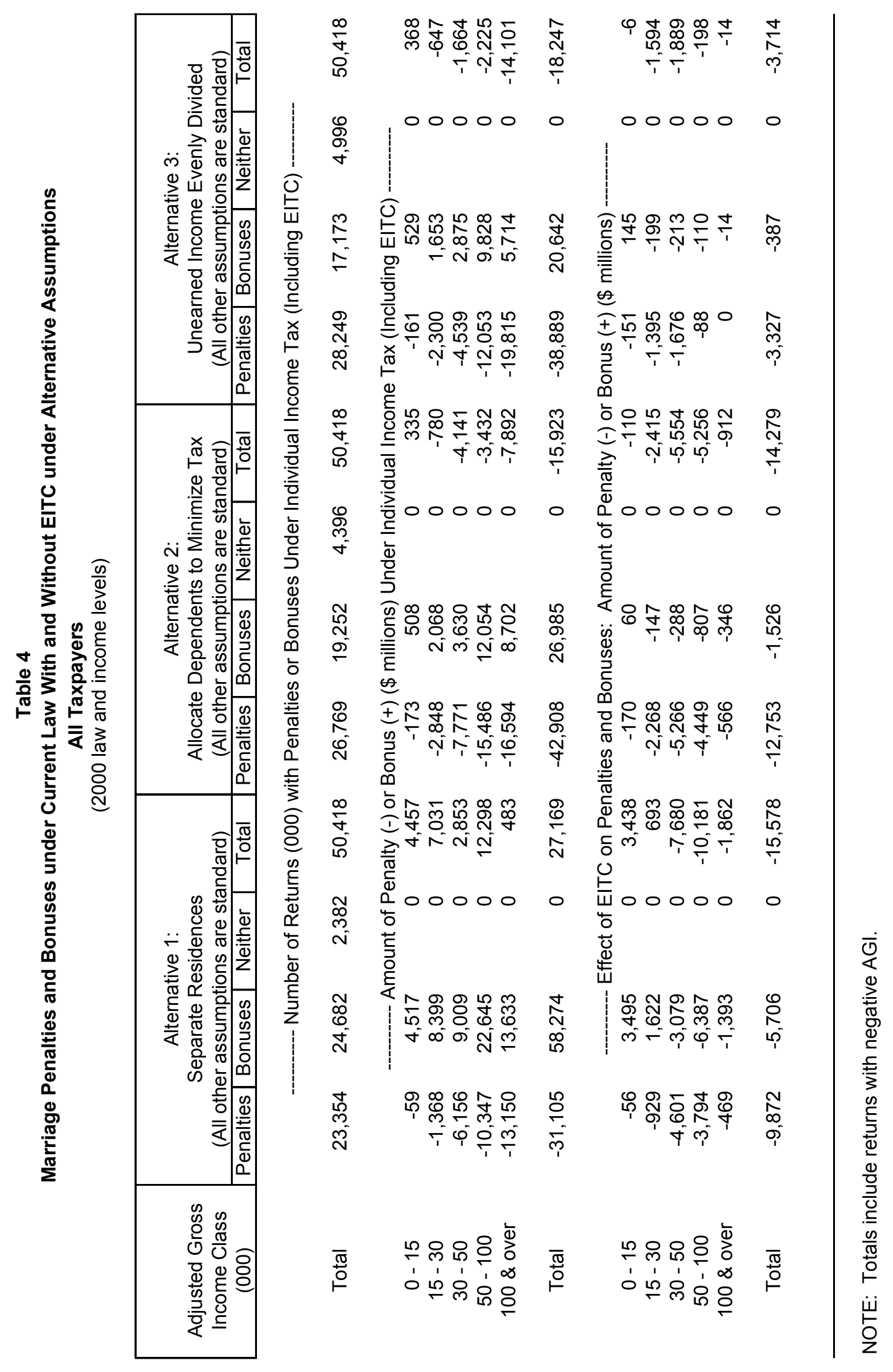




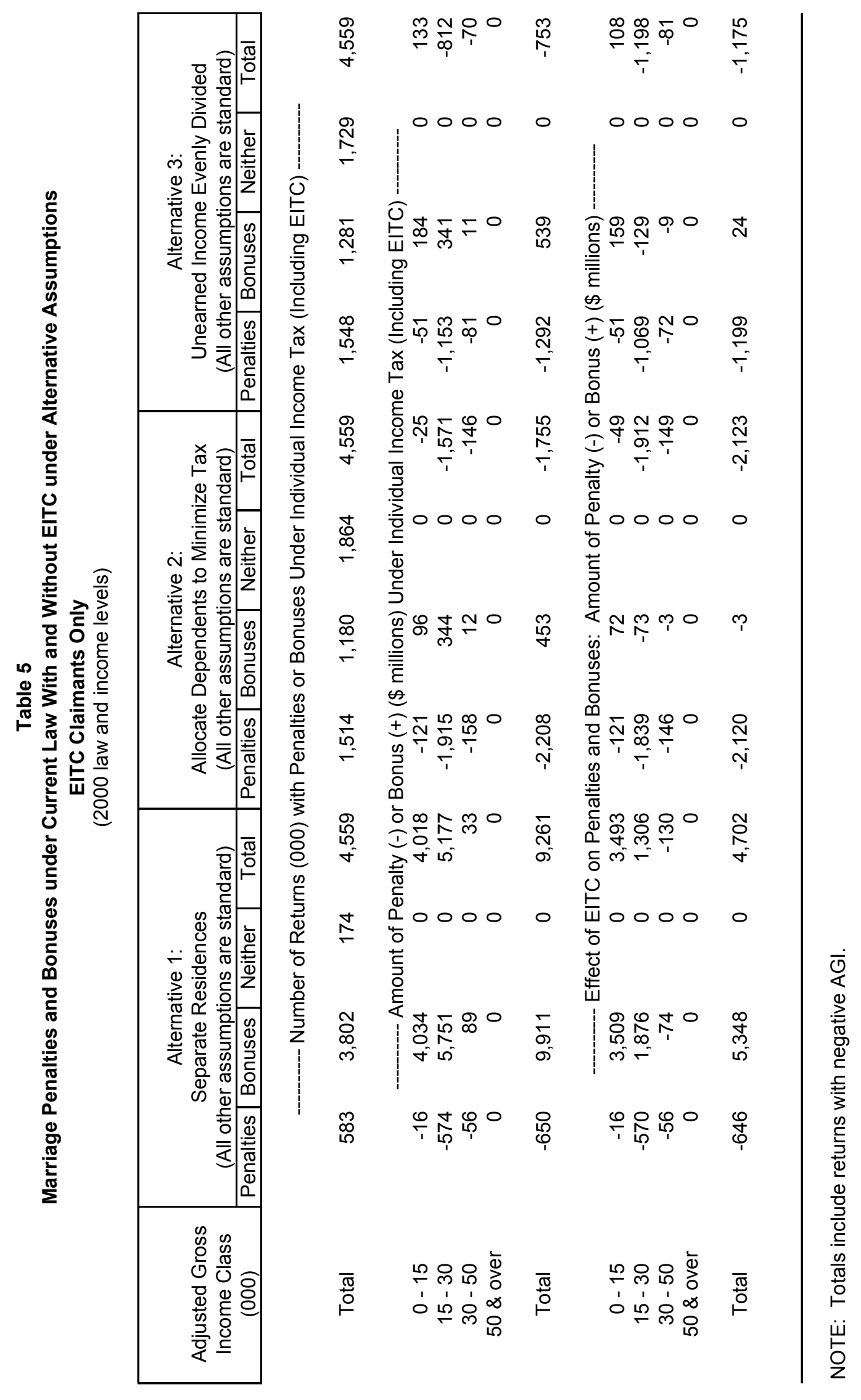




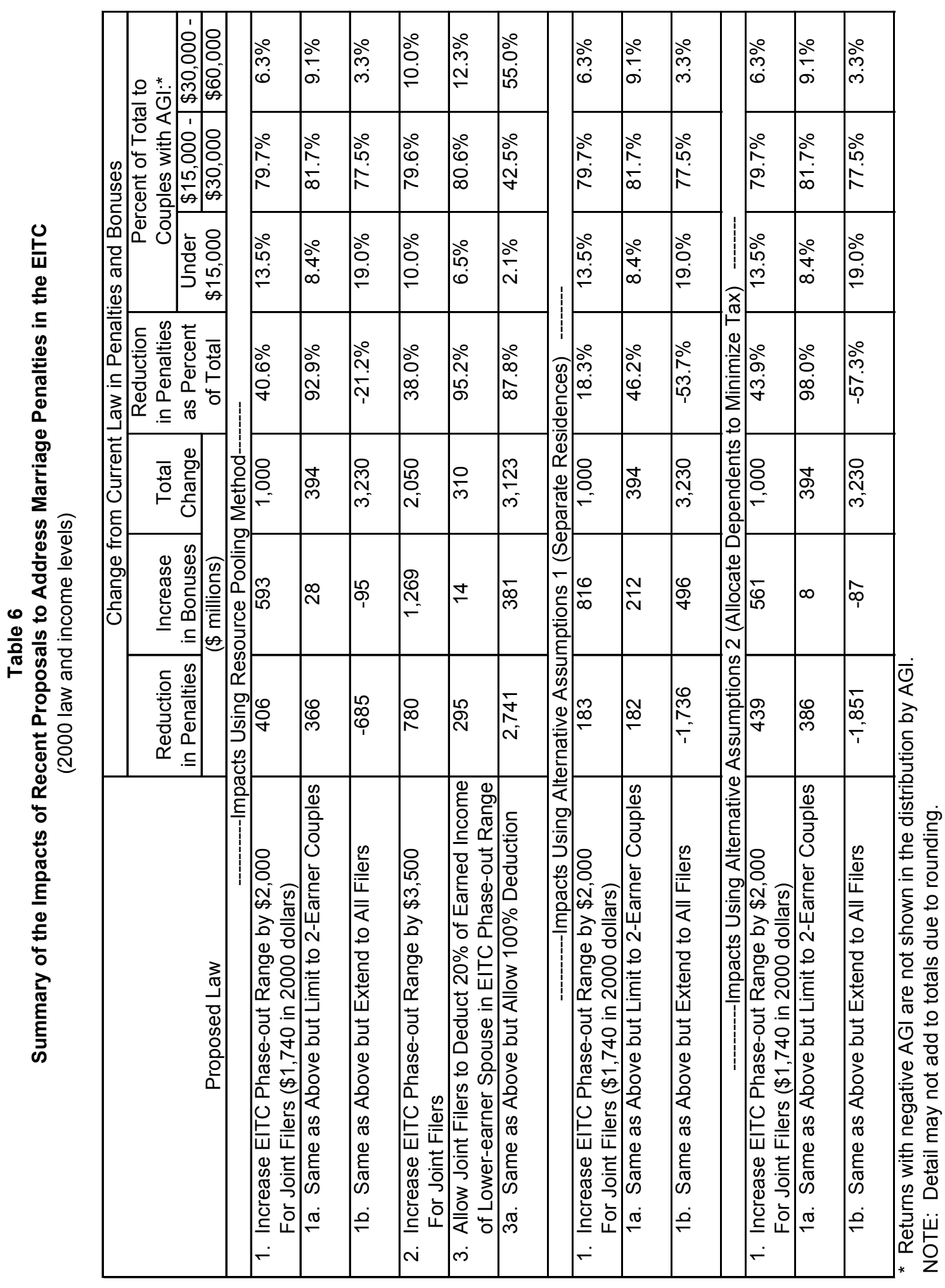

